\title{
A multivariate approach to differentiate yerba mate (Ilex paraguariensis) commercialized in the southern Brazil on the basis of phenolics, methylxanthines and in vitro antioxidant activity
}

\author{
Acácio Antonio Ferreira ZIELINSKI ${ }^{1 *}$ (D), Aline ALBERTI², Evandro BONA³ ${ }^{3}$ Débora Gonçalves BORTOLINI², \\ Laís BENVENUTTI ${ }^{1}$, Fabiane BACH ${ }^{4}$, Ivo Mottin Demiate ${ }^{2}$, Alessandro NOGUEIRA ${ }^{2}$
}

\begin{abstract}
The consumption of yerba mate beverages is related to several health benefits. These desirable properties are mainly due to the bioactive compounds. However, the levels of those compounds are directly affected by factors such as geographical origin. This study aimed to use chemometrics to evaluate the antioxidant compounds of yerba mate (consumed as chimarrão) marketed in southern Brazil. Neochlorogenic acid and caffeine were the main bioactive compounds found in this type of yerba mate beverage (chimarrão). The dataset was analyzed by chemometrics, and principal component analysis using the first three principal components explained $61.30 \%$ of the total variance. Hierarchical cluster analysis suggested three clusters, with cluster 1 containing the majority of the samples from the states of Rio Grande do Sul and Paraná, with higher levels of phenolics, methylxanthines, and antioxidant activity. The supervised methods, soft independent modeling of class analogy (SIMCA) and partial least squares-discriminant analysis (PLS-DA), had similar predictability ( $\geq 75 \%$ of accuracy) in terms of classifying yerba mate according to different Brazilian regions. Therefore, the chemometric tools used in the current study was suitable to monitor and assess a large variation of the antioxidant composition of yerba mate from different southern Brazilian states.
\end{abstract}

Keywords: bioactive compounds; geographical origin; chimarrão; HPLC; pattern recognition.

Practical Application: The use of chemometrics to discrimination and classification of commercial yerba mate.

\section{Introduction}

Yerba mate is the main product prepared from the dried and ground, leaves and twigs obtained from the Ilexparaguariensis A. St.-Hil. (Aquifoliaceae) tree. According to the Food and Agricultural Organization of the United Nations (2017), Brazil is the largest producer of the yerba mate worldwide, with around 602,000 tonnes per year, followed by Argentina (237,000 tonnes), and Paraguay (92,000 tonnes). Its natural occurrence is located in the latitude at $22^{\circ} \mathrm{S}$ to $30^{\circ} \mathrm{S}$ and longitude at $48^{\circ} 30^{\prime} \mathrm{W}$ to $56^{\circ} 10^{\prime} \mathrm{W}$, with an altitude of 500-1500 m.a.s.l and a normal annual rainfall of 1500-2000 $\mathrm{mm}$, and medium temperature of $15-18^{\circ} \mathrm{C}$ (Empresa Brasileira de Pesquisa Agropecuária, 2017).

Traditionally yerba mate is consumed as a hot infusion, which is known as 'chimarrão' in southern Brazil (Colpo et al., 2016). The beverage (chimarrão) is made in a typical artefact denominated 'cuia' where the yerba mate is added and partially immersed in hot water (around $80^{\circ} \mathrm{C}$ ). Once the infusion is ready, this extract is drunk using a metal straw 'bomba' (Silveira et al., 2016b). During consumption, water is poured over the yerba mate many times to make a partial infusion, and about $20-40 \mathrm{~mL}$ of fresh extract is drunk each time (Bracesco et al., 2011). Furthermore, it is important to emphasize that the drinking process is continuous all day long and throughout the year, usually accompanying daily activities, with an average consumption of 1-2 L per day per consumer.

Its proximate composition, expressed in dry matter, showed around $1.2 \%$ of protein, $10.4 \%$ of carbohydrates, and $0.8 \%$ of total fat, and has interesting contents of potassium (1100 mg/100 g), magnesium (296 mg/100 g), and manganese (54.4 mg/100 g) (Cardozo \& Morand, 2016). The intake of yerba mate beverages, which is mainly by people from South America, is related to several health benefits that have been reported in the literature, including antioxidant, antimutagenic, anticancer, anti-inflammatory, and antimicrobial effects, as well as lipid reduction and vasodilation properties (Heck \& Mejia, 2007; Bracesco et al., 2011; Silveira et al., 2016a; Gerke et al., 2017). These desirable properties are mainly due to the bioactive compounds (phenolic compounds and methylxanthines) in yerba mate, which have been attributed to antioxidant activity. The phenolic compounds in yerba mate beverages (chimarrão or mate) are mostly represented by chlorogenic acids (Silveira et al., 2016b). The main methylxanthines, on the other hand, are caffeine and theobromine (Bassani et al., 2007).

The levels of those bioactive compounds are directly affected by factors such as geographical origin, as well as variations in 
environmental conditions, processing and cultivation, harvest time, and soil composition (Pinto et al., 2015; Bastos et al., 2018). In southern Brazil there are a large number of brands of yerba mate that are commercialized from different regions, and the antioxidant potential of each of these is influenced by the factors mentioned above. Nowadays, the differences in foods that are mainly related to their geographical origin are investigated using the combination of analytical results and multivariate statistical tools (Herrera Alvarez et al., 2017; Bona et al., 2017). This association makes it possible to extract a maximum quantity of information from the dataset and it increases understanding about the data structure (Zielinski et al., 2014b).

Therefore, the aim of this study was to evaluate the chemical composition of yerba mate (to be used as chimarrão) marketed in southern Brazil in order to discriminate and classify the samples according to their geographical origin using multivariate statistical analysis.

\section{Materials and methods}

\subsection{Materials}

A total of 69 samples (around $10 \mathrm{~kg}$ each sample) of yerba mate (to be consumed as chimarrão) from three different Brazilian states (Paraná - PR; Santa Catarina - SC; and Rio Grande do Sul - RS) were purchased in the respective local markets from 2015 to 2016. Their geographical origin was stated by yerba mate companies. All the packages stated that the yerba mate was derived from the I. paraguariensis species. Folin-Ciocalteu reagent $(2.0 \mathrm{~N})$, DPPH (2,2-diphenyl-1-picrylhydrazyl), ABTS (2,2'-azino-bis(3-ethylbenzothiazoline-6-sulfonic acid)), TPTZ (2,4,6-tri (2-pyridyl)-s-triazine), trolox (6-hydroxy-2,5,7,8-tet ramethylchroman-2-carboxylic acid), gallic acid, chlorogenic acid, caffeine, theobromine and rutin were all purchased from Sigma-Aldrich (St. Louis, MO, USA), with purity $\geq 95 \%$ (HPLC-grade standards). The other reagents used in the experiments were of analytical grade and all the solutions were prepared using Milli-Q water (MILLI-Q, Millipore, Brazil).

\subsection{Yerba mate infusion}

Initially, each sample (10 kg, moisture content of $10 \%)$ was quartered, and $100 \mathrm{~g}$ was ground to obtain a homogeneous fine powder that passed through a $0.5 \mathrm{~mm}$ screen. Then, $2 \mathrm{~g}$ of each sample was extracted with $100 \mathrm{~mL}$ of distilled water at $80^{\circ} \mathrm{C}$ under constant agitation (150 rpm in a magnetic stirrer) for eight min, in accordance with Zielinski et al. (2014a). All the infusions were centrifuged $\left(8160 \times g, 20 \mathrm{~min}\right.$ at $\left.4^{\circ} \mathrm{C}\right)$, transferred to Falcon tubes, and immediately frozen at $-20^{\circ} \mathrm{C}$ until further analysis.

\subsection{Phenolic and methylxantine composition}

The total phenolic content (TPC) was determined in the extracts according to Singleton \& Rossi (1965) using Folin-Ciocalteu reagent, with minor modifications. The analysis was performed in 96-well microplates, where $15 \mu \mathrm{L}$ of diluted extracts, $240 \mu \mathrm{L}$ of distilled water and $15 \mu \mathrm{L}$ of Folin-Ciocalteu reagent $(0.2 \mathrm{~N})$ were added. After three min under agitation, $30 \mu \mathrm{L}$ of sodium carbonate solution $(1.0 \mathrm{~N})$ was added into the microplates, followed by gentle shaking for five minutes in a vortex. The absorbance $(725 \mathrm{~nm})$ was measured after 30 minutes using a microplate reader (Epoch microplate spectrophotometer, Synergy-BIOTEK, Winooski, VT, USA). The absorbance values of the samples were compared with a calibration curve of gallic acid (GA) and the results were expressed as $\mathrm{mg}$ of gallic acid equivalents (GAE) per liter of infusion [mg GAE/L].

The total flavonols were determined in triplicate, as described by Kumaran \& Karunakaran (2007), with minor modifications. Briefly, in microplates, $30 \mu \mathrm{L}$ of each infusion was mixed with $60 \mu \mathrm{L}$ of aluminum chloride $(20 \mathrm{mg} / \mathrm{mL})$ and $150 \mu \mathrm{L}$ of sodium acetate $(50 \mathrm{mg} / \mathrm{mL})$. The solution was kept in the dark for 2.5 hours and the absorbance was measured at $440 \mathrm{~nm}$ using a microplate reader (Epoch microplate spectrophotometer, Synergy-BIOTEK, Winooski, VT, USA). The sample absorbance measurements were compared to a calibration curve of rutin and the results were expressed as milligrams of rutin equivalents (RE) per liter of infusion [mg RE/L].

The identification and quantification of individual phenolic compounds and methylxantines was performed by high performance liquid chromatography (HPLC) according to Mejía et al. (2010), with slight modifications. Prior to analysis, the samples were filtered through a $0.20 \mu \mathrm{m}$ nylon syringe and $10 \mu \mathrm{L}$ of the sample was injected into the chromatography system. The separation was performed using an Alliance HPLC system (model 2695, Waters, Milford, MA, USA), coupled with a photodiode array detector (model PDA 2998, Waters, Milford, MA, USA), a quaternary pump and an auto sampler. Separation was performed using a Gemini ${ }^{\circledR} \mathrm{C}_{18}$ column with dimensions of $150 \mathrm{~mm} \times 4.6 \mathrm{~mm}, 5 \mu \mathrm{m}$ (Phenomenex, Torrance, CA, USA) at $25^{\circ} \mathrm{C}$ with a flow rate of $0.9 \mathrm{~mL} / \mathrm{min}$. A linear gradient composed of mobile phase A ( $1.0 \%$ formic acid, $\mathrm{v} / \mathrm{v})$ and mobile phase B (acetonitrile) was applied from 3 to $45 \%$ B for $45 \mathrm{~min}$, followed by the washing and reconditioning of the column. The peaks were compared to the retention time and the wavelengths of the standards, and the areas were compared against the regression equations of the standards $\left(\mathrm{R}^{2}>0.99, p<0.01\right)$. The runs were monitored at $320 \mathrm{~nm}$ (chlorogenic acids), and at $350 \mathrm{~nm}$ (rutin). All the results were expressed as milligrams per liter of infusion $[\mathrm{mg} / \mathrm{L}]$. A typical chromatogram is presented in Figure 1.

\subsection{In vitro antioxidant activity}

The measurement of the free-radical scavenging activity by the DPPH assay of the yerba mate infusions was performed according to Brand-Williams et al. (1995). The samples were submitted to reading in a microplate reader (Epoch microplate spectrophotometer, Synergy-BioTek, Winooski, VT, USA) at $517 \mathrm{~nm}$.

The measurement of the free-radical scavenging activity by the ABTS assay was performed as described by Re et al. (1999). The mixture reacted in the dark for $30 \mathrm{~min}$ and the measurement was performed using a microplate reader (Epoch microplate spectrophotometer, Synergy-BioTek, Winooski, VT, USA) at $734 \mathrm{~nm}$.

The measurement of the total antioxidant potential by the FRAP method was performed according to Benzie \& Strain 


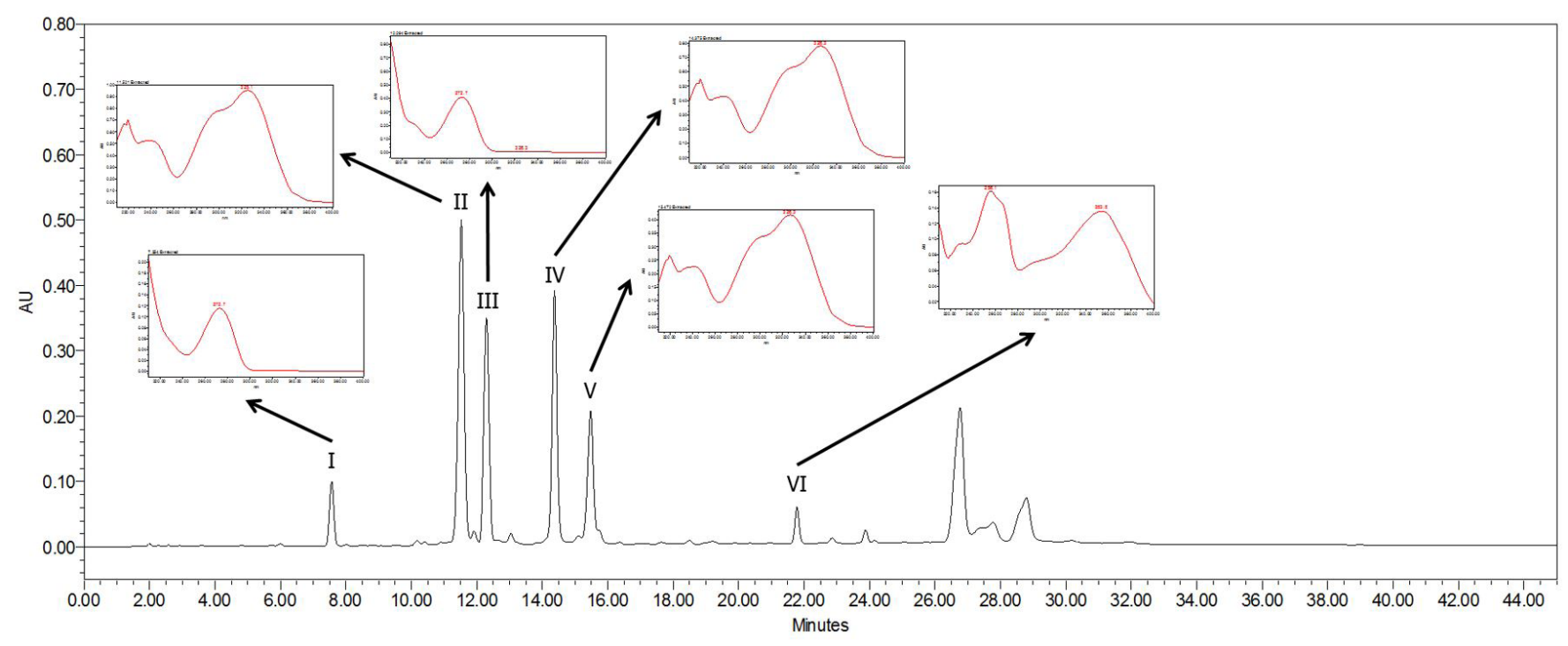

Figure 1. Typical chromatogram obtained from yerba mate extract ("chimarrão") for phenolic compounds and methylxanthines (280 nm). The UV spectra corresponding to the compounds are shown above the chromatogram. Peaks: (I) theobromine; (II) neochlorogenic acid; (III) caffeine; (IV) chlorogenic acid; (V) cryptochlorogenic acid; and (VI) rutin.

(1996). The reading was performed in a microplate reader (Biotec Instruments, Inc., Epoch, Winooski, USA) at $593 \mathrm{~nm}$.

For all the in vitro antioxidant activity, a standard curve was plotted using different concentrations of Trolox $(100-1000 \mu \mathrm{mol} / \mathrm{L})$. The results were expressed in $\mu \mathrm{mol}$ Trolox equivalent per liter of infusion $(\mu \mathrm{mol} \mathrm{TE} / \mathrm{L})$. All the determinations were performed in quadruplicate.

\subsection{Data analysis}

The data were presented as median and mean \pm standard deviation (SD). All the data had their normality checked by the Shapiro-Wilk test, and their homogeneity of variance were verified by Levene's test. A significant difference between the samples from the Brazilian states was found by one-way ANOVA (parametric data) and Kruskal-Wallis ANOVA (non-parametric data). Furthermore, all the analytical parameters and samples were evaluated together by multivariate statistical tools. Firstly, all the variables were autoscaled (into z-score) and then principal component analysis (PCA) was used to separate the samples according to their phenolic and methylxanthine contents and in vitro antioxidant activity. Hierarchical cluster analysis (HCA) was applied to check the similarities between the samples based on the Euclidean distance. Ward's method was used to suggest clusters as the samples in the same group were considered to be statistically similar (Zielinski et al., 2014b).

An attempt to classify in accordance with geographical origin was also performed by soft independent modeling of class analogy (SIMCA), and partial least squares-discriminant analysis (PLS-DA). For classification, the dataset was divided into a training set $(75 \%)$ and validation set $(25 \%)$ by the Kennard-Stone algorithm. For SIMCA, each category was independently modeled using PCA. The number of PCs in each class ranged from 3 to 5 . In addition, the class distance was determined by considering that each class was bounded by a region of space, which represents a confidence level of $95 \%$ (Herrera Alvarez et al., 2017). For the PLS-DA, the number of latent variables was defined using 10 -fold cross-validation of calibration samples based on the mean of the areas under the receiver operating characteristic curve (ROC) for each class (Bona et al., 2017). The PLS-DA output was converted into a posteriori probabilities using Bayes' Theorem. Thereafter, a threshold value for the class separation was obtained and the performance of the classifier was evaluated using the figures of merit which had been previously defined (Marquetti et al., 2016).

The performance of the models was evaluated by means of the accuracy, sensitivity, specificity, and efficiency, Equations 1, 2, 3, and 4:

$$
\begin{aligned}
& \mathrm{ACCY}=100 \times \frac{(\mathrm{TP}+\mathrm{TN})}{(\mathrm{TP}+\mathrm{TN}+\mathrm{FP}+\mathrm{FN})} \\
& \mathrm{SENS}=100 \times \frac{\mathrm{TP}}{(\mathrm{TP}+\mathrm{FN})} \\
& \mathrm{SPEC}=100 \times \frac{\mathrm{TN}}{(\mathrm{TN}+\mathrm{FP})} \\
& \mathrm{EFFI}=\frac{\text { SENS }+\mathrm{SPEC}}{2}
\end{aligned}
$$

where: ACCY is accuracy; SENS is sensitivity; SPEC is specificity; EFFI is efficiency; TP is the number of positive samples that are correctly identified as positive samples; FN is the number of positive samples that are misclassified as negative samples; FP is the number of negative samples that are incorrectly identified as positive samples; and TN is the number of negative samples that are correctly identified as negative samples. 
The PCA and SIMCA were performed using Pirouette 4.1 software (Infometrix ${ }^{\circledR}$, Bothell, WA, USA). The PLS-DA was performed using MATLAB R2008b (The MathWorks Inc., Natick, USA) and HCA was performed using Statistica v. 13.3 (TIBCO Software Inc., Palo Alto, CA, USA).

\section{Results and discussion}

The minimum, maximum and mean values of the yerba mate extracts are shown in Table 1. The total phenolics and total flavonols ranged from 500 to $1,531 \mathrm{mg} \mathrm{GAE} / \mathrm{L}$ (median: 1,061 mg GAE/L), and from 230 to $541 \mathrm{mg} \mathrm{RE} / \mathrm{L}$ (median: $349 \mathrm{mg} / \mathrm{L}$ ), respectively. The methylxanthines, represented by caffeine and theobromine, varied from 66 to $201 \mathrm{mg} / \mathrm{L}$ (median: $140 \mathrm{mg} / \mathrm{L}$ ), and from 334 to $904 \mathrm{mg} / \mathrm{L}$ (median: $542 \mathrm{mg} / \mathrm{L}$ ), respectively. In terms of the individual phenolics, neochlorogenic acid ranged from 259 to $635 \mathrm{mg} / \mathrm{L}$ (median: $487 \mathrm{mg} / \mathrm{L}$ ), chlorogenic acid from 204 to $359 \mathrm{mg} / \mathrm{L}$ (median: $275 \mathrm{mg} / \mathrm{L}$ ), cryptochlorogenic acid from 132 to $257 \mathrm{mg} / \mathrm{L}$ (median: $179 \mathrm{mg} / \mathrm{L}$ ), and rutin from 36 to $105 \mathrm{mg} / \mathrm{L}$ (median: $69 \mathrm{mg} / \mathrm{L}$ ). Statistically significant differences were not observed $(p>0.05)$ between the geographical origin of the samples of Brazilian yerba mate (Table 1), except for neochlorogenic acid $(p=0.01)$, which was present at a higher concentration in the samples from Rio Grande do Sul $(n=31)$.

According to Peres et al. (2013), caffeoylquinic acids like neochlorogenic (183-263 mg/L), chlorogenic (153-242 mg/L), and cryptochlorogenic (123-188 mg/L) acids are the major phenolic compounds found in yerba mate beverages (chimarrão and tererê); neochlorogenic acid stands out as having higher levels in these beverages. Butiuk et al. (2016) observed that the leaves and stems from the early harvesting season have the highest chlorogenic acid content; and the roasting step during yerba mate processing is responsible for a substantial loss of this phenolic acid. In the present study, significant correlation coefficients $(p<0.01)$ were observed between neochlorogenic and chlorogenic acids $(r=0.40)$ and with TPC ( $r=0.42, r=0.38$, respectively). Furthermore, the consumption of caffeoylquinic acids from yerba mate beverages can contribute to the prevention of chronic and cardiovascular diseases (Cardozo \& Morand, 2016). Theobromine, caffeine, and rutin have also been found in I. paraguariensis (Souza et al., 2015; Baeza et al., 2018). Methylxanthines presents good hydroxyl radical scavenging ability which is attributed their anticarcinogenic properties (Zielinski et al., 2016). As reported by Silveira et al. (2014), yerba mate beverages also are good sources of rutin (flavonol), confirming the significant correlation $(p<0.05)$ in our study between flavonols and TPC $(r=0.44, r=0.24)$ for the analyzed samples.

Chemical methods are the main and easiest techniques to measure the in vitro antioxidant activity of foods and beverages. However, these methods differ in their mechanisms and some problems have been reported. Therefore, the in vitro antioxidant activity was estimated by using three different methods (ABTS, DPPH and FRAP) (Table 1). The radical scavenging determined by ABTS ranged from 9,840 to $16,209 \mu \mathrm{mol}$ TE/L (median: $12,988 \mu \mathrm{mol} / \mathrm{L}$ ) and by DPPH from 8,869 to $24,793 \mu \mathrm{mol}$ TE/L (median: 16,248 $\mu \mathrm{mol} / \mathrm{L}$ ). The total antioxidant potential measured by FRAP varied from 6,265 to $17,252 \mu \mathrm{mol}$ TE/L (median: $11,829 \mu \mathrm{mol} / \mathrm{L}$ ). In our study, the ABTS assay was the most suitable method to measure antioxidant activity. Its results showed correlation with those of the other spectrophotometric methods that were used $(r>0.32, p<0.03)$, and the individual phenolics and methylxanthines that were evaluated $(r>0.26$,

Table 1. Phenolics, methylxanthines and in vitro antioxidant actitivity of Brazilian Yerba Mate according to the geographical origin.

\begin{tabular}{|c|c|c|c|c|}
\hline Analytical parameters & $\begin{array}{c}\text { Paraná } \\
(\mathrm{n}=21)\end{array}$ & $\begin{array}{c}\text { Santa Catarina } \\
(\mathrm{n}=17)\end{array}$ & $\begin{array}{l}\text { Rio Grande do Sul } \\
(\mathrm{n}=31)\end{array}$ & p-value \\
\hline TPC (mg GAE/L) & $\begin{array}{l}1019.4 \pm 276.6 \\
(500.0-1520.8)\end{array}$ & $\begin{array}{l}1033.3 \pm 276.6 \\
(611.1-1493.9)\end{array}$ & $\begin{array}{l}1067.8 \pm 288.4 \\
(624.1-1531.3)\end{array}$ & 0.77 \\
\hline Flavonols (mg RE/L) & $\begin{array}{c}366.9 \pm 72.4 \\
(274.5-540.8)\end{array}$ & $\begin{array}{c}332.2 \pm 58.7 \\
(230.4-429.2)\end{array}$ & $\begin{array}{c}364.9 \pm 61.9 \\
(262.6-477.8)\end{array}$ & 0.19 \\
\hline ABTS $(\mu \mathrm{mol}$ TE/L) & $\begin{array}{l}12887.0 \pm 1358.6 \\
(9839.5-15304.8)\end{array}$ & $\begin{array}{c}12434.0 \pm 1409.0 \\
(10271.2-15081.8)\end{array}$ & $\begin{array}{c}13144.7 \pm 1477.9 \\
(10014.1-16209.2)\end{array}$ & 0.26 \\
\hline $\mathrm{DPPH}(\mu \mathrm{mol} \mathrm{TE} / \mathrm{L})$ & $\begin{array}{c}16120.1 \pm 2685.6 \\
(12131.2-21955.4)\end{array}$ & $\begin{array}{l}15382.0 \pm 3712.2 \\
(8869.3-23450.9)\end{array}$ & $\begin{array}{c}16829.6 \pm 2860.9 \\
(10329.9-24793.3)\end{array}$ & 0.29 \\
\hline FRAP $(\mu \mathrm{mol} \mathrm{TE} / \mathrm{L})$ & $\begin{array}{l}11831.3 \pm 2392.6 \\
(6264.5-16464.3)\end{array}$ & $\begin{array}{l}11397.7 \pm 2210.1 \\
(8122.2-15780.8)\end{array}$ & $\begin{array}{l}12329.9 \pm 1966.8 \\
(8560.3-17251.9)\end{array}$ & 0.35 \\
\hline Theobromine (mg/L) & $\begin{array}{l}127.6 \pm 29.6 \\
(65.8-193.9)\end{array}$ & $\begin{array}{l}144.0 \pm 36.2 \\
(72.7-200.6)\end{array}$ & $\begin{array}{l}143.6 \pm 31.1 \\
(69.8-196.3)\end{array}$ & 0.17 \\
\hline Neochlorogenic acid $(\mathrm{mg} / \mathrm{L})$ & $\begin{array}{l}464.4^{\mathrm{b}} \pm 65.5 \\
(356.0-592.1)\end{array}$ & $\begin{array}{l}440.0^{\mathrm{b}} \pm 75.5 \\
(259.0-569.2)\end{array}$ & $\begin{array}{l}505.5^{\mathrm{a}} \pm 63.5 \\
(376.9-635.4)\end{array}$ & 0.01 \\
\hline Caffeine $(\mathrm{mg} / \mathrm{L})$ & $\begin{array}{c}543.5 \pm 143.8 \\
(333.54-839.3)\end{array}$ & $\begin{array}{l}546.5 \pm 111.2 \\
(356.7-754.3)\end{array}$ & $\begin{array}{l}599.2 \pm 121.6 \\
(423.2-904.4)\end{array}$ & 0.21 \\
\hline Chlorogenic acid $(\mathrm{mg} / \mathrm{L})$ & $\begin{array}{c}284.2 \pm 34.5 \\
(206.4-359.2)\end{array}$ & $\begin{array}{c}269.0 \pm 36.4 \\
(204.4-318.7)\end{array}$ & $\begin{array}{c}271.4 \pm 27.1 \\
(222.3-332.3)\end{array}$ & 0.26 \\
\hline Cryptochlorogenic acid (mg/L) & $\begin{array}{c}189.6 \pm 29.0 \\
(131.7-257.1)\end{array}$ & $\begin{array}{c}174.8 \pm 17.3 \\
(142.8-205.7)\end{array}$ & $\begin{array}{c}176.6 \pm 19.5 \\
(142.6-231.2)\end{array}$ & 0.07 \\
\hline Rutin (mg/L) & $\begin{array}{l}68.8 \pm 16.5 \\
(37.3-105.1)\end{array}$ & $\begin{array}{l}62.0 \pm 10.8 \\
(39.3-77.6)\end{array}$ & $\begin{array}{c}72.5 \pm 16.2 \\
(35.6-104.9)\end{array}$ & 0.08 \\
\hline
\end{tabular}

*Probability values obtained by one-way ANOVA. TPC: total phenolic compounds, and in vitro antioxidant activity by ABTS: 2,2'-azino-bis(3-ethylbenzothiazoline-6-sulfonic acid); DPPH: 2,2-diphenyl-1-picrylhydrazyl; FRAP: ferric reducing antioxidant power. 
$p<0.03)$ except for rutin $(r=0.21, p=0.08)$. The same was observed by Deetae et al. (2012), who evaluated the antioxidant properties of Thai herbal teas and conventional teas. The ABTS assay has advantages over the other assays because it is able to react with both hydrophilic and hydrophobic antioxidants, therefore covering a broader range of antioxidants in a sample (Gorjanović et al., 2012).

As observed in our study, a high variation regarding the phenolic composition and in vitro antioxidant activity of yerba mate can be due to the manufacturing conditions. Briefly, the following processing steps are involved in the production of commercial yerba mate: harvesting, roasting, drying, milling, aging, and packing. Furthermore, the companies that process yerba mate employ different conditions, which can modify the qualitative and quantitative phenolic composition. Isolabella et al. (2010) observed that zapecado (roasting or pre-drying), drying and aging steps changed the biologically active principles of the samples. In addition, each company uses different leaf-to-stem ratios, and I. paraguariensis trees grow in many different climatic and geographical locations (Butiuk et al., 2016; Souza et al., 2015; Marquez et al., 2013). The leaves of Ilex paraguariensis show higher levels of phenolic compounds and higher antioxidant capacity than stems (Souza et al., 2015), and the harvest season influences the composition of both leaves and stems (Butiuk et al., 2016). Therefore, the wide range that was observed in the raw materials explains the low significant $(p<0.05)$ correlation coefficients that were found between all the parameters.

As well as the previously mentioned factors that influence the levels of antioxidant compounds, it is important to emphasize that yerba mate beverages (chimarrão or mate and tererê) are consumed with successive infusions in southern Brazil, Argentina and Uruguay. According to Colpo et al. (2016), antioxidant compounds can be extracted in different amounts during the consumption of chimarrão.

In order to explore the differences between the samples from the distinct Brazilian regions that were studied, principal component analysis (PCA) was performed. Principal component 1 (PC1) explained up to $37.64 \%$ of total variance, PC2 explained $13.20 \%$, and PC3 explained $10.47 \%$, totaling $61.30 \%$. Using a
3D-scatter plot, it was possible to observe an overlap between the samples from Rio Grande do Sul (RS), Santa Catarina (SC) and Paraná (PR) (Figure 2A). However, the majority of the samples from RS remained associated, while the samples from SC and PR showed a higher dispersion. The clearest separation was observed when PCA was conducted again using the SC and RS samples (53.74\% of total variance explained by the two first PCs); there was a higher number of RS samples on the right side (Figure 2B). On the other hand, the PCA applied between the samples from PR and RS, and PR and SC, continued to overlap (Figures 2C, 2D). In contrast to our study, Marcelo et al. (2014) used PCA and reported a clear separation between yerba mate samples from different countries (Brazil, Argentina, Uruguay, and Paraguay); they considered mineral analysis to discriminate the country of origin.

In addition to PCA, the similarity between the samples was also evaluated using HCA and three clusters were suggested (Figure 3 ). Cluster 1 mainly grouped samples from RS (50\%, 16 samples) and PR (31\%, ten samples), and showed significant difference using one-way ANOVA $(p<0.01)$ between clusters 2 and 3 (Table 2 ), with higher levels in all the analyzed parameters (phenolics, methylxanthines, and antioxidant activity). Cluster 2 was also mainly formed by samples from RS (53\%, ten samples), and cluster 3 by samples from SC (39\%, seven samples).

A tentative classification of the yerba mate samples according to geographical origin was also performed by SIMCA and PLS-DA. The SIMCA model was developed with the selection of four principal components for each Brazilian state class (Paraná, Santa Catarina, and Rio Grande do Sul), which was able to explain more than $79 \%$ of the total variance in each class. Furthermore, the model had an overall accuracy of $84 \%$ (external validation of 75\%). The PLS-DA model, with seven latent variables, explained $99.99 \%$ of variance in $\mathrm{X}$ and $17.49 \%$ in $Y$. The low variance of $Y$ indicates that the variables of $X$ did not show a satisfactory correlation with the classes represented in Y. The overall accuracy that was determined was $75 \%$ (external validation of $81 \%$ ). The classification achieved by both proposed models to differentiate yerba mate from different Brazilian states (PR, SC and RS) showed similar performance, with a consistency in the efficiency, sensitivity and specificity values (Table 3 ).

Table 2. Chemical composition of yerba mate samples clustered using hierarchical cluster analysis.

\begin{tabular}{|c|c|c|c|c|c|}
\hline Variables & $\begin{array}{c}\text { Cluster } 1 \\
(\mathrm{n}=32)\end{array}$ & $\begin{array}{c}\text { Cluster } 2 \\
(\mathrm{n}=19)\end{array}$ & $\begin{array}{c}\text { Cluster } 3 \\
(\mathrm{n}=18)\end{array}$ & $\mathrm{p}$-value & p-value $e^{* *}$ \\
\hline TPC (mg GAE/L) & $1166 \pm 214$ & $1074 \pm 176.49$ & $796.81 \pm 180.96$ & 0.10 & $<0.01$ \\
\hline Flavonols (mg RE/L) & $401.97 \pm 58.92$ & $329.57 \pm 42.59$ & $307.75 \pm 39.47$ & 0.99 & $<0.01$ \\
\hline DPPH $(\mu \mathrm{mol}$ TE/L) & $17371 \pm 3038$ & $15934 \pm 2900$ & $14618 \pm 2500$ & 0.20 & $<0.01$ \\
\hline FRAP $(\mu \mathrm{mol} \mathrm{TE} / \mathrm{L})$ & $12572 \pm 1644$ & $12265 \pm 2286$ & $10507 \pm 2288$ & 0.40 & $<0.01$ \\
\hline Caffeine (mg/L) & $638.04 \pm 116.56$ & $523.11 \pm 97.80$ & $495.62 \pm 114.14$ & 0.62 & $<0.01$ \\
\hline Chlorogenic acid $(\mathrm{mg} / \mathrm{L})$ & $291.69 \pm 26.61$ & $267.29 \pm 13.57$ & $252.32 \pm 38.53$ & 0.01 & $<0.01$ \\
\hline Cryptochlorogenic acid (mg/L) & $193.43 \pm 23.35$ & $171.49 \pm 10.70$ & $165.59 \pm 18.65$ & 0.07 & $<0.01$ \\
\hline Rutin (mg/L) & $76.24 \pm 13.87$ & $69.38 \pm 12.46$ & $54.93 \pm 11.90$ & 0.73 & $<0.01$ \\
\hline
\end{tabular}

Results expressed as mean \pm standard deviation. TPC: total phenolic compounds, and in vitro antioxidant activity by ABTS: 2,2'-azino-bis(3-ethylbenzothiazoline-6-sulfonic acid); DPPH: 2,2-diphenyl-1-picrylhydrazyl; FRAP: ferric reducing antioxidant power. ${ }^{*}$ Probability values obtained by the Levene test for homogeneity of variances; ${ }^{\star *}$ Probability values obtained by one-way ANOVA or Kruskal-Wallis test. Different letters in the same line represent statistically different results $(\mathrm{P}<0.05)$. 


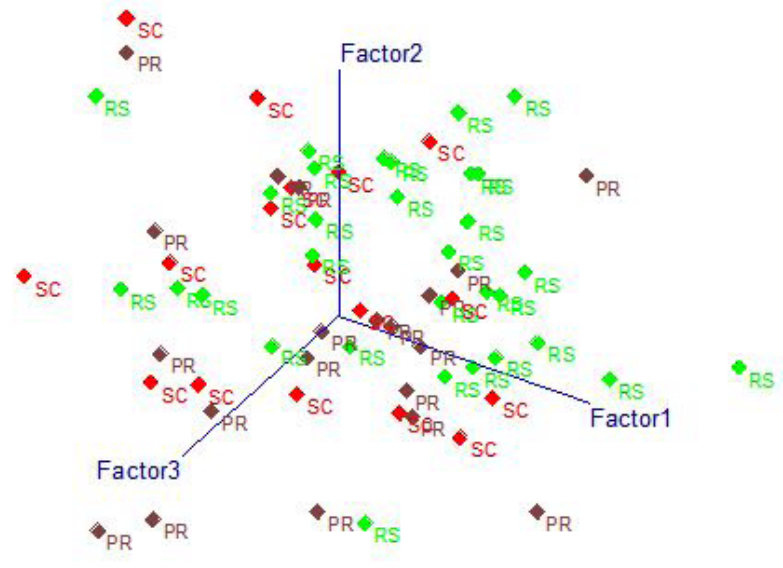

$$
\bullet \mathrm{PR}
$$

(A)

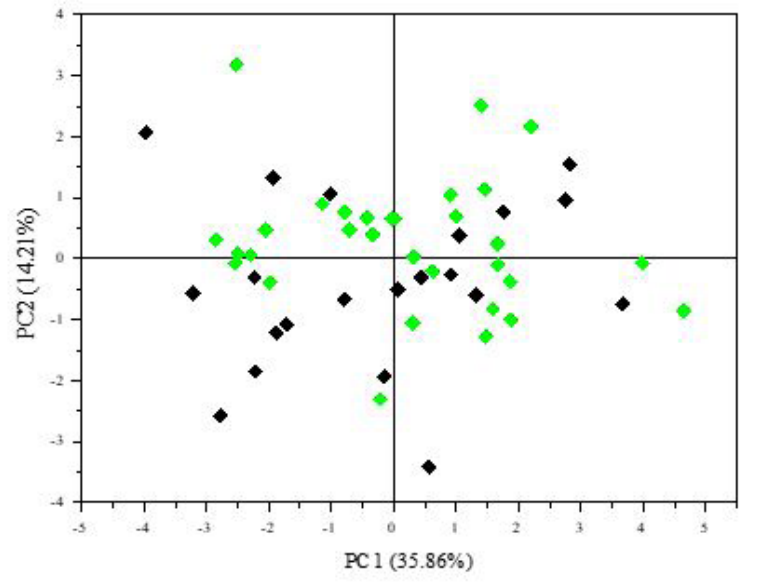

(C)

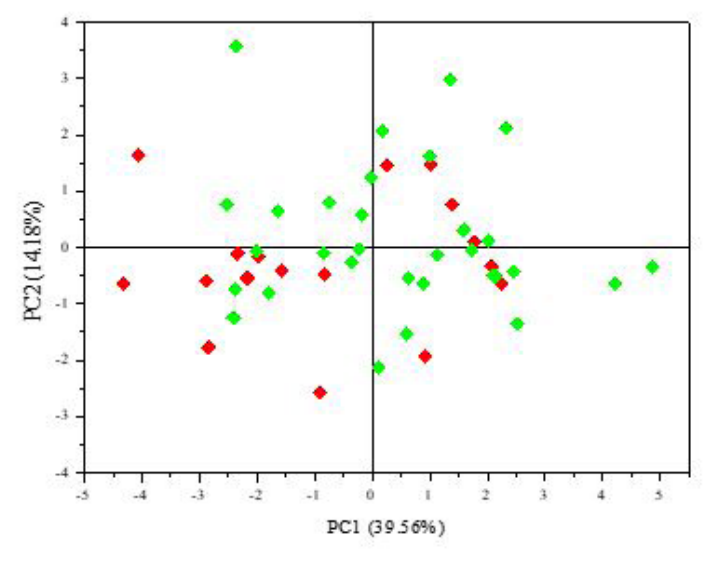

(B)

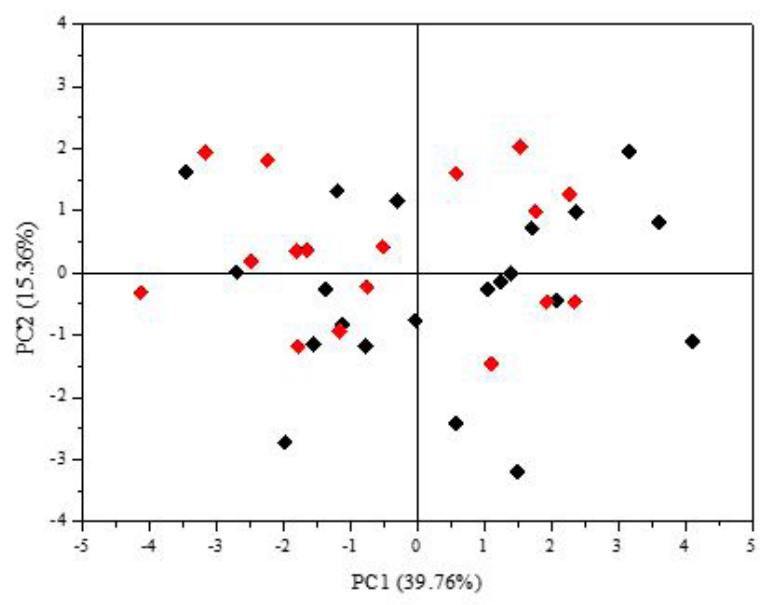

(D)

Figure 2. PCA scatter plots obtained for all samples (A), SC vs. RS (B), PR vs. RS (C), PR vs. SC (D). Note: red (Santa Catarina), black (Paraná), green (Rio Grande do Sul). PC1: Principal component 1; PC2: Principal component 2; RS: Rio Grande do Sul; SC: Santa Catarina; PR: Parana.

Table 3. Predictive abilities of classification models (SIMCA and PLS-DA) using the chemical dataset for Yerba Mate samples produced in Paraná (PR), Santa Catarina (SC) and Rio Grande do Sul (RS).

\begin{tabular}{|c|c|c|c|c|c|c|c|}
\hline \multirow{2}{*}{\multicolumn{2}{|c|}{ Predictive abilities }} & \multicolumn{3}{|c|}{ Calibration } & \multicolumn{3}{|c|}{ Validation } \\
\hline & & \multirow{2}{*}{$\begin{array}{c}\text { PR } \\
86.00\end{array}$} & \multirow{2}{*}{$\frac{\text { SC }}{84.00}$} & \multirow{2}{*}{$\begin{array}{c}\text { RS } \\
82.00\end{array}$} & \multirow{2}{*}{$\begin{array}{c}\text { PR } \\
78.95\end{array}$} & \multirow{2}{*}{$\frac{\text { SC }}{73.68}$} & \multirow{2}{*}{$\begin{array}{c}\text { RS } \\
73.68\end{array}$} \\
\hline SIMCA (\%) & Accuracy & & & & & & \\
\hline \multirow{7}{*}{ PLS-DA (\%) } & Sensitivity & 80.00 & 83.33 & 69.57 & 66.67 & 80.00 & 50.00 \\
\hline & Specificity & 88.57 & 84.21 & 92.59 & 84.62 & 71.43 & 90.91 \\
\hline & Efficiency & 84.29 & 83.77 & 81.08 & 75.64 & 75.71 & 70.45 \\
\hline & Accuracy & 80.00 & 76.00 & 68.00 & 68.42 & 84.21 & 89.47 \\
\hline & Sensitivity & 46.67 & 33.33 & 89.47 & 33.33 & 40.00 & 100.00 \\
\hline & Specificity & 94.29 & 89.47 & 66.67 & 84.62 & 100.00 & 81.82 \\
\hline & Efficiency & 70.48 & 61.40 & 78.07 & 58.98 & 70.00 & 90.91 \\
\hline
\end{tabular}




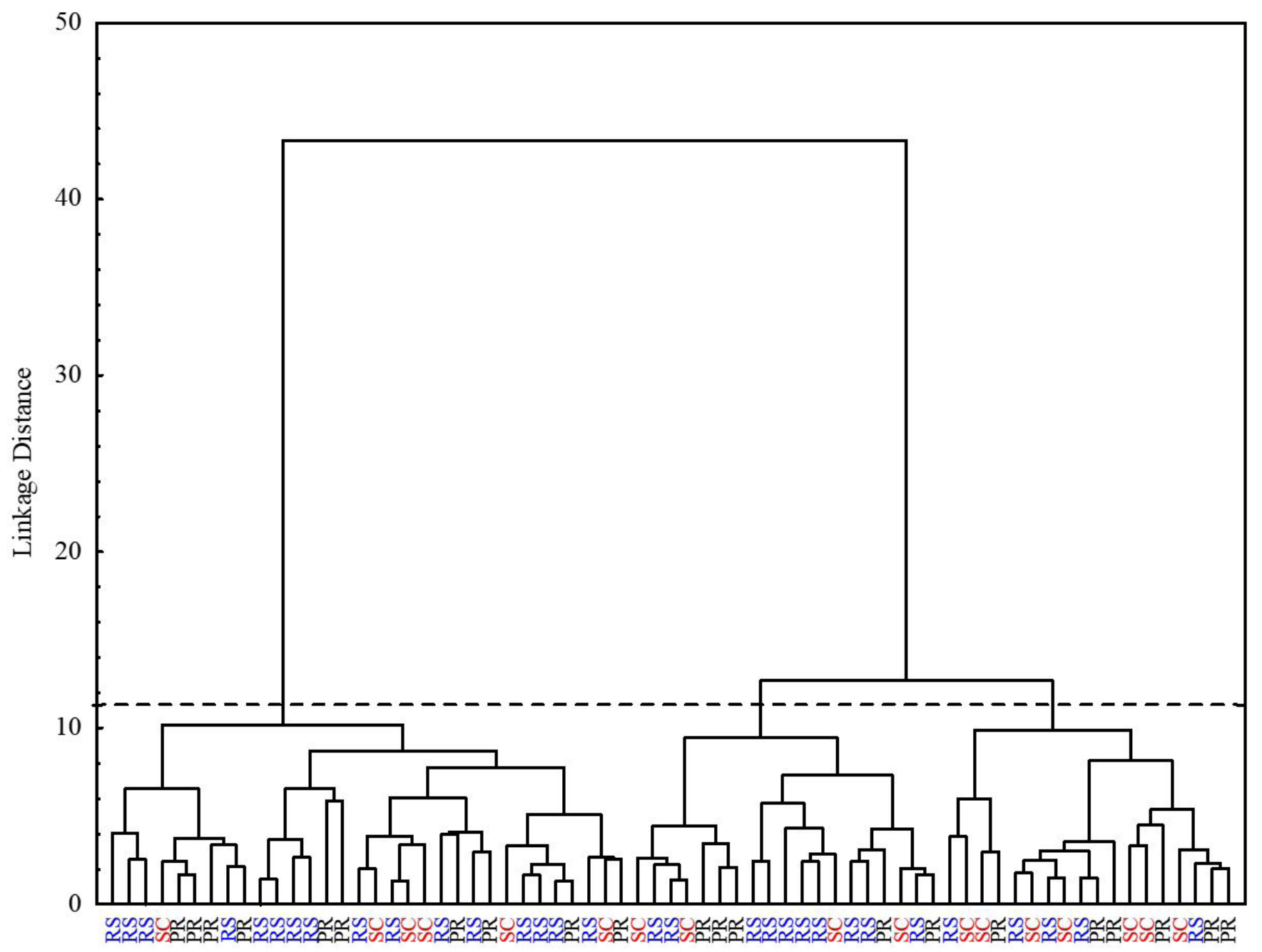

Figure 3. Dendrogram obtained by HCA for yerba mate samples produced in the southern Brazil. RS: Rio Grande do Sul; SC: Santa Catarina; PR: Parana.

Although, our results had intermediate levels $(<80 \%$ of accuracy) of classification, as far as we know this is the first study that has used antioxidant composition together with chemometrics to differentiate and classify yerba mate according to geographical origin (Brazilian states). Therefore, the methods that were employed can be useful for the quality control of yerba mate and its correct classification according to geographical origin.

\section{Conclusion}

A large variation in the level of antioxidant compounds was verified between the yerba mate samples from different southern Brazilian states. Using PCA, the first three principal components explained $61.30 \%$ of total variance, with the majority of the samples from RS staying associated; while the samples from SC and PR overlapped. Furthermore, HCA suggested three clusters, with cluster 1 (mainly samples from RS and PR) showing the highest levels of phenolics, methylxanthines, and antioxidant activity. A tentative classification of yerba mate according to geographical origin was also performed and both models that were employed (SIMCA and PLS-DA) had a similar predictability
( $\geq 75 \%$ of accuracy). Therefore, the chemometric tools used in the current study can be suitable to monitor and assess the antioxidant composition of yerba mate and also to suggest its correct classification according to its geographical origin.

\section{Acknowledgements}

The authors are grateful to the National Council for Scientific and Technological Development, and the Coordination for the Improvement of Personnel in Higher Education for financial support and scholarships.

\section{References}

Baeza, G., Sarriá, B., Bravo, L., \& Mateos, R. (2018). Polyphenol content, in vitro bioacessibility and antioxidant capacity of widely consumed beverages. Journal of the Science of Food and Agriculture, 98(4), 1397-1406. http://dx.doi.org/10.1002/jsfa.8607. PMid:28771735.

Bassani, V. L., Gnoatto, S. C. B., Coelho, G. C., \& Schenkel, E. P. (2007). Influência do método de extração nos teores de metilxantinas em erva mate (Ilex paraguariensis A. St. Hil. Aquilofoliaceae). Química Nova, 30(2), 304-307. http://dx.doi.org/10.1590/S0100-40422007000200012. 
Bastos, M. C., Cherobim, V. F., Reissmann, C. B., Kaseker, J. F., \& Gaiad, S. (2018). Yerba mate: Nutrient levels and quality of the beverage depending on the harvest season. Journal of Food Composition and Analysis, 69, 1-6. http://dx.doi.org/10.1016/j.jfca.2018.01.019.

Benzie, I. F. F., \& Strain, J. J. (1996). The ferric reducing ability of plasma (FRAP) as a measure of "antioxidant power": the FRAP assay. Analytical Biochemistry, 239(1), 70-76. http://dx.doi.org/10.1006/ abio.1996.0292. PMid:8660627.

Bona, E., Marquetti, I., Link, J. V., Makimori, G. Y. F., Arca, V. C., Lemes, A. L. G., Ferreira, J. M. G., Scholz, M. B. S., Valderrama, P., \& Poppi, R. J. (2017). Support vector machines in tandem with infrared spectroscopy for geographical classification of green arabica coffee. Lebensmittel-Wissenschaft + Technologie, 76, 330-336. http:// dx.doi.org/10.1016/j.lwt.2016.04.048.

Bracesco, N., Sanchez, A. G., Contreras, V., Menini, T., \& Gugliucci, A. (2011). Recent advances on Ilex paraguariensis research: minireview. Journal of Ethnopharmacology, 136(3), 378-384. http://dx.doi. org/10.1016/j.jep.2010.06.032. PMid:20599603.

Brand-Williams, W., Cuvelier, M. E., \& Berset, C. (1995). Use of a free radical method to evaluate antioxidant activity. LebensmittelWissenschaft + Technologie, 28(1), 25-30. http://dx.doi.org/10.1016/ S0023-6438(95)80008-5.

Butiuk, A. P., Martos, M. A., Adachi, O., \& Hours, R. (2016). Study of the chlorogenic acid content in Yerba maté (Ilex paraguariensis St. Hil.): effect of plant fraction, processing step and harvesting season. Journal of Applied Research on Medicinal and Aromatic Plants, 3(1), 27-33. http://dx.doi.org/10.1016/j.jarmap.2015.12.003.

Cardozo, E. L. Jr., \& Morand, C. (2016). Interest of mate (Ilex paraguariensis A. St.-Hil.) as a new natural functional food to preserve human cardiovascular health: a review. Journal of Functional Foods, 21, 440-454. http://dx.doi.org/10.1016/j.jff.2015.12.010.

Colpo, A. C., Rosa, H., Lima, M. E., Pazzini, C. E. F., Camargo, V. B., Bassante, F. E. M., Puntel, R., Ávila, D. S., Mendez, A., \& Folmer, V. (2016). Yerba mate (Ilex paraguariensis St. Hill.)-based beverages: How successive extraction influences the extract composition and its capacity to chelate iron and scavenge free radicals. Food Chemistry, 209, 185-195. http://dx.doi.org/10.1016/j.foodchem.2016.04.059. PMid:27173551.

Deetae, P., Parichanon, P., Trakunleewatthana, P., Chanseetis, C., \& Lertsiri, S. (2012). Antioxidant and anti-glycation properties of Thai herbal teas in comparison with conventional teas. Food Chemistry, 133(3), 953-959. http://dx.doi.org/10.1016/j.foodchem.2012.02.012.

Empresa Brasileira de Pesquisa Agropecuária - EMBRAPA. (2017). A erva-mate. Brasília. Retrieved from https://www.embrapa.br/en/ florestas/transferencia-de-tecnologia/erva-mate

Food and Agricultural Organization of the United Nations - FAO. FAOSTAT. (2017). FAO statistical database. Rome. Retrieved from http://faostat3.fao.org/

Gerke, I. B. B., Hamerski, F., Scheer, A. P., \& Silva, V. R. (2017). Clarification of crude extract of yerba mate (Ilex paraguariensis) by membrane processes: analysis of fouling and loss of bioactive compounds. Food and Bioproducts Processing, 102, 204-212. http:// dx.doi.org/10.1016/j.fbp.2016.12.008.

Gorjanović, S., Komes, D., Pastor, F. T., Belščak-Cvitanović, A., Pezo, L., Hečimović, I., \& Sužnjević, D. (2012). Antioxidant capacity of teas and herbal infusions: polarographic assessment. Journal of Agricultural and Food Chemistry, 60(38), 9573-9580. http://dx.doi. org/10.1021/jf302375t. PMid:22950743.

Heck, C. I., \& Mejia, E. G. (2007). Yerba mate tea (Ilex paraguariensis): a comprehensive review on chemistry, health implications, and technological considerations. Journal of Food Science, 72(9), 138-151. http://dx.doi.org/10.1111/j.1750-3841.2007.00535.x. PMid:18034743.

Herrera Alvarez, L. V., Zielinski, A. A. F., Alberti, A., \& Nogueira, A. (2017). Monitoring of the phenolic compounds and in vitro antioxidant activity of apple beverages according to geographical origin and their type: A chemometric study. Lebensmittel-Wissenschaft + Technologie, 84, 385-393. http://dx.doi.org/10.1016/j.lwt.2017.05.078.

Isolabella, S., Cogoi, L., López, P., Anesini, C., Ferraro, G., \& Filip, R. (2010). Study of the bioactive compounds variation during yerba mate (Ilex paraguariensis) processing. Food Chemistry, 122(3), 695699. http://dx.doi.org/10.1016/j.foodchem.2010.03.039.

Kumaran, A., \& Karunakaran, R. J. (2007). In vitro antioxidant activities of methanol extracts of five Phyllanthus species from India. Lebensmittel-Wissenschaft + Technologie, 40(2), 344-352. http://dx.doi.org/10.1016/j.lwt.2005.09.011.

Marcelo, M. C. A., Martins, C. A., Pozebon, D., Dressler, V. L., \& Ferrão, M. F. (2014). Classification of yerba mate (Ilex paraguariensis) according to the country of origin based on element concentrations. Microchemical Journal, 117, 164-171. http://dx.doi.org/10.1016/j. microc.2014.06.027.

Marquetti, I., Link, J. V., Lemes, A. L. G., Scholz, M. B. S., Valderrama, P., \& Bona, E. (2016). Partial least square with discriminant analysis and near infrared spectroscopy for evaluation of geographic and genotypic origin of arabica coffee. Computers and Electronics in Agriculture, 121, 313-319. http://dx.doi.org/10.1016/j.compag.2015.12.018.

Marquez, V., Martínez, N., Guerra, M., Fariña, L., Boido, E., \& Dellacassa, E. (2013). Characterization of aroma-impact compounds in yerba mate (Ilex paraguariensis) using GC-olfactometry and GC-MS. Food Research International, 53(2), 808-815. http://dx.doi.org/10.1016/j. foodres.2013.02.016.

Mejía, E. G., Song, Y. S., Heck, C. I., \& Ramírez-Mares, M. (2010). Yerba mate tea (Ilexparaguariensis): phenolics, antioxidant capacity and in vitro inhibition of colon cancer cell proliferation. Journal of Functional Foods, 2(1), 23-34. http://dx.doi.org/10.1016/j.jff.2009.12.003.

Peres, R. G., Tonin, F. G., Tavares, M. F. M., \& Rodriguez-Amaya, D. B. (2013). HPLC-DAD-ESI/MS identification and quantification of phenolic compounds in Ilex paraguariensis beverages and on-line evaluation of individual antioxidant activity. Molecules, 18(4), 30593871. http://dx.doi.org/10.3390/molecules18043859. PMid:23538900.

Pinto, R. M. C., Lemes, B. M., Zielinski, A. A. F., Klein, T., Paula, F., Kist, A., Marques, A. S. F., Nogueira, A., Demiate, I. M., \& Beltrame, F. L. (2015). Detection and quantification of phytochemical markers of Ilex paraguariensis by liquid chromatography. Química Nova, 38, 1219-1225.

Re, R., Pellegrini, N., Proteggente, A., Pannala, A., Yang, M., \& RiceEvans, C. (1999). Antioxidant activity applying an improved ABTS radical cation decolorization assay. Free Radical Biology \& Medicine, 26(9-10), 1231-1237. http://dx.doi.org/10.1016/S0891-5849(98)003153. PMid:10381194.

Silveira, T. F. F., Meinhart, A. D., Ballus, C. A., \& Godoy, H. T. (2014). The effect of the duration of infusion, temperature, and water volume on the rutin content in the preparation of mate tea beverages: an optimization study. Food Research International, 60, 241-245. http:// dx.doi.org/10.1016/j.foodres.2013.09.024.

Silveira, T. F. F., Meinhart, A. D., Coutinho, J. P., Souza, T. C. L., Cunha, E. C. E., Moraes, M. R., \& Godoy, H. T. (2016a). Content of lutein in aqueous extracts of yerba mate (Ilex paraguariensis St. Hil). Food Research International, 82, 165-171. http://dx.doi.org/10.1016/j. foodres.2015.12.033.

Silveira, T. F. F., Meinhart, A. D., Souza, T. C. L., Teixeira, J. Fo., \& Godoy, H. T. (2016b). Phenolic compounds from yerba mate based beverages: 
a multivariate optimization. Food Chemistry, 190, 1159-1167. http:// dx.doi.org/10.1016/j.foodchem.2015.06.031. PMid:26213090.

Singleton, V., \& Rossi, J. A. (1965). Colorimetry of total phenolics with phosphobolybdic-phosphotungstic acid reagents. American Journal of Enology and Viticulture, 14, 144-158.

Souza, A. H. P., Corrêa, R. C. G., Barros, L., Calhelha, R. C., SantosBuelga, C., Peralta, R. M., Bracht, A., Matsushita, M., \& Ferreira, I. C. F. R. (2015). Phytochemicals and bioactive properties of Ilex paraguariensis: An in-vitro comparative study between the whole plant, leaves and stems. Food Research International, 78, 286-294. http://dx.doi.org/10.1016/j.foodres.2015.09.032. PMid:28433294.

Zielinski, A. A. F., Haminiuk, C. W. I., \& Beta, T. (2016). Multi-response optimization of phenolic antioxidants from white tea (Camellia sinensis L. Kuntze) and their identification by LC-DAD-Q-TOF-MS/
MS. Lebensmittel-Wissenschaft + Technologie, 65, 897-907. http:// dx.doi.org/10.1016/j.lwt.2015.09.020.

Zielinski, A. A. F., Haminiuk, C. W. I., Alberti, A., Nogueira, A., Demiate, I. M., \& Granato, D. (2014a). A comparative study of the phenolic compounds and the in vitro antioxidant activity of different Brazilian teas using multivariate statistical techniques. Food Research International, 60, 246-254. http://dx.doi.org/10.1016/j. foodres.2013.09.010.

Zielinski, A. A. F., Haminiuk, C. W. I., Nunes, C. A., Schnitzler, E., van Ruth, S. M., \& Granato, D. (2014b). Chemical composition, sensory properties, provenance, and bioactivity of fruit juices as assessed by chemometrics: a critical review and guideline. Comprehensive Reviews in Food Science and Food Safety, 13(3), 300-316. http:// dx.doi.org/10.1111/1541-4337.12060. 